\title{
Sex Ratio in an Island Population of Clethrionomys glareolus (Schreber, 1780)
}

\author{
Gabriela BUJALSKA
}

\begin{abstract}
Bujalska G., 1986: Sex ratio in an island population of Clethrionomys glareolus (Schreber, 1780). Acta theriol., 31, 5: 71-78 [With 1 Table \& 3 Figs.]

A long-term study of an island population of the bank vole showed sex ratio among trappable voles close to 1, though at low population numbers numcical prevalence of females over males was frequent. Among mature individuals the females were usually more numerous than the males. Mortality rate of mature males was higher than that of mature females. A lower maturation rate was found for males than for females. Relative numerical stability with different levels for mature males and females was evidenced. Hence, sex ratio in mature voles showed tendency toward prevalence of females during population increase. Spacing behaviour (a possible mechanism for regulation of natality) could be responsible for the changes in sex ratio among mature individuals.

[Institute of Ecology, PAS, Dziekanów Leśny, 05-092 Łomianki, Poland]
\end{abstract}

\section{INTRODUCTION}

Seasonal changes of sex ratio in small rodents were studied by Bergstedt (1965), Lidicker (1973) and Hansson (1978). Separate sex ratio estimates for mature and immature individuals were published by $\mathrm{Pe}-$ likán (1970) and Kalela (1971), and mechanisms governing the proportions of the sexes were investigated by Myers and Krebs (1971) and Redfield et al. (1978).

In this report attention is paid to the sex ratio in mature voles, i.e., those having definite spacing behaviour and "responsible" for reproduction (Bujalska, 1970, 1973). It seemed reasonable that sex ratio in mature voles may reflect, or be related to regulatory processes.

\section{STUDY AREA AND METHODS}

Crabapple Island on Beldany Lake in Northeastern Poland was the sampling area. The vegetation of the island is mostly deciduous forest, which is a typical habitat for the bank vole (Pucek, 1983). The entire 4 ha island was evenly covered with 159 trap sites visited twice daily for each 7 day census. The population was sampled 5 times a year at 6 -week intervals from April to October.

The CMR method was applied, and made possible exact estimates of the size of the trappable population by means of the "census method". Estimates obtained 
this way were highly correlated with those made by Jolly's (1965) method (Bujalska, 1985).

The accepted criterion of male maturity was scrotal testes. A series of vaginal smears served to distinguish between mature and immature females (Bujalska, 1970). The sex ratio in mature voles was studied in $1975-80$, and that in all the trappable individuals was investigated also in $1966-70$ and in 1972.

In this paper the sex ratio is given as the number of males to females: $\bar{z}=m / f$. For each census it was possible to calculate a mean ratio of males to females, based on individuals newly caught on consecutive days. This made it possible to estimate the standard error and $95 \%$ confidence interval for $\bar{z}$, according to Dunin-Barkovskij \& Smirnov (1955):

$$
\sigma_{z}=\sqrt{\frac{\sigma_{m}^{2}}{\left(E_{f}\right)^{2}}+\frac{\left(E_{m}\right)^{2}}{\left(E_{f}\right)^{4}} \sigma_{f}^{2}-2 \frac{E_{m}}{\left(E_{f}\right)^{3}} C_{m f}}
$$

The following sample estimates were accepted:

$$
\begin{aligned}
& E_{m} \cong \bar{m} ; \quad E_{f} \cong \bar{f} ; \quad \sigma_{m}^{2}=S_{m b}^{2}: \sigma_{f}^{2}=S_{f}^{2} \\
& \bar{m}=\frac{1}{n} \sum_{i=1}^{n} m_{i}: \bar{f}=\frac{1}{n} \sum_{i=1}^{n} f_{i} \\
& S_{m}^{2}=\frac{1}{n} \sum_{i=1}^{n} m_{i}^{2}-\bar{m}^{2} ; S_{f}^{2}=\frac{1}{n} \sum_{i=1}^{n} f_{i}^{2}-\bar{f}^{2} \\
& C_{m f}=\frac{1}{n} \sum_{i=1}^{n} m_{i} f_{i}-\bar{m} \bar{f}
\end{aligned}
$$

where: $n$ - number of subsamples (time units) in a census, $m_{i}-$ number of males in subsample $i, f_{i}-$ number of females in subsample $i(i=1,2,3, \ldots n)$.

\section{RESULTS}

First, the $\bar{z}$ values for the trappable voles were plotted against the population size (Fig. 1). It appears that significant $(p<0.05)$ deviations from 1 are more numerous for $\bar{z}<1$ than for $\bar{z}>1$. If they were randomly distributed around 1 one should expect the same number of significant deviations in each direction. The Chi-square test confirms, 
however, that $\bar{z}$ was significantly $<1$ more frequently than expected $\left(\chi^{2}=5.042, d . f .=1, p<0.05\right.$, tko-tailed test $)$.

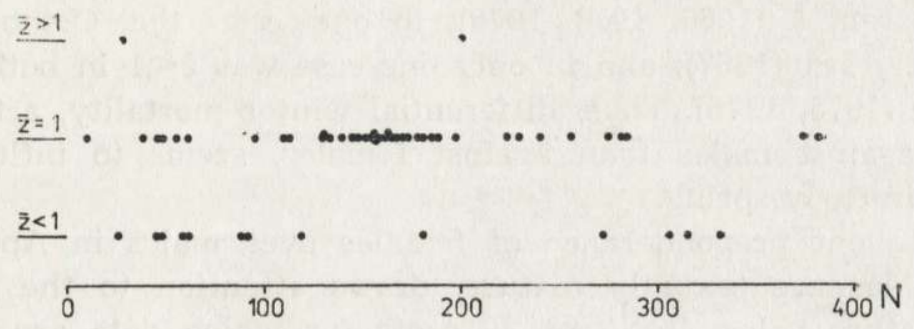

Fig. 1. Sex ratio in trappable voles at different population sizes.

$\bar{z}-$ estimate of sex ratio $(\bar{z}>1$ or $\bar{z}<1$ significant at $p<0.05), N-$ population numbers.

Also the frequency of significant deviations $(z \neq 1)$ varies with population size (Bujalska, 1981a, 1983). Low numbers are defined as encompassing the range $1-133$; intermediate numbers run from 134-266 ; and high numbers are those from 267-400. When frequency of significant deviations from $\bar{z}=1$ is compared among these three groups there is no difference between high and low populations, but intermediate populations have significantly fewer different $\bar{z}$ values than low populations do $\left(\chi^{2}=4.324\right.$, d.f. $\left.=1, p<0.05\right)$.

A closer examination of the deviations at low density (total number $<133$; density $<35$ voles per ha) shows that 5 cases of $\bar{z} \neq 1$ (including the one case of $\bar{z}>1$ ) occured in April, 3 cases of $\bar{z} \neq 1$ occured in June, and one in July. The sex ratio in April deserves particular attention because the population then consists of overwintered voles only, and their number is highly correlated with food availability (Bujalska, 1985).

Table 1

Sex ratio estimate for trappable population in October and the following April

\begin{tabular}{llccccc}
\hline \multirow{2}{*}{ Year } & \multicolumn{2}{c}{ October } & & \multicolumn{2}{c}{ April } \\
\cline { 2 - 3 } \cline { 5 - 6 } & $\bar{z}$ & $95 \%$ c.l. & & Year & $\bar{z}$ & $95 \%$ c.1. \\
\hline 1966 & 0.998 & $0.848-1.149$ & 1967 & 0.616 & $0.416-0.817$ \\
1967 & 1.436 & $1.416-1.455$ & 1968 & 0.707 & $0.647-0.768$ \\
1968 & 0.928 & $0.632-1.232$ & 1969 & 0.773 & $0.586-0.959$ \\
1969 & 0.933 & $0.814-1.062$ & 1970 & 1.108 & $0.795-1.420$ \\
1975 & 0.857 & $0.783-0.931$ & 1976 & 0.688 & $0.526-0.850$ \\
1976 & 0.845 & $0.424-1.266$ & 1977 & 0.880 & $0.849-0.911$ \\
1977 & 0.922 & $0.778-1.066$ & 1978 & 1.087 & $0.138-2.036$ \\
1978 & 0.768 & $0.427-1.109$ & 1979 & 1.136 & $0.004-2.276$ \\
1979 & 0.931 & $0.500-1.362$ & 1980 & 0.833 & $0.168-1.834$ \\
\hline
\end{tabular}


The April sex ratio seems to be independent of the sex ratio in the previous October (Table 1). In 5 of 9 Aprils $\bar{z}$ was significantly $<1$. In three of those cases $\bar{z}$ in the previous October was not significantly different from $1(1966,1968,1976)$; in one case the October $\bar{z}$ was significantly $>1$ (1967); and in only one case was $\bar{z}<1$ in both October and April $(1975,1976)$. Thus, differential winter mortality, acting more strongly against males than against females, seems to influence the sex ratio in early spring.

The frequent preponderance of females over males in April, when all the voles are sexually mature, draws attention to the sex ratio among mature voles. In 17 of 30 cases for which data are available a significant preponderance of mature females over mature males was found. In the remaining 13 cases $\bar{z}$ did not deviated significantly from 1 .

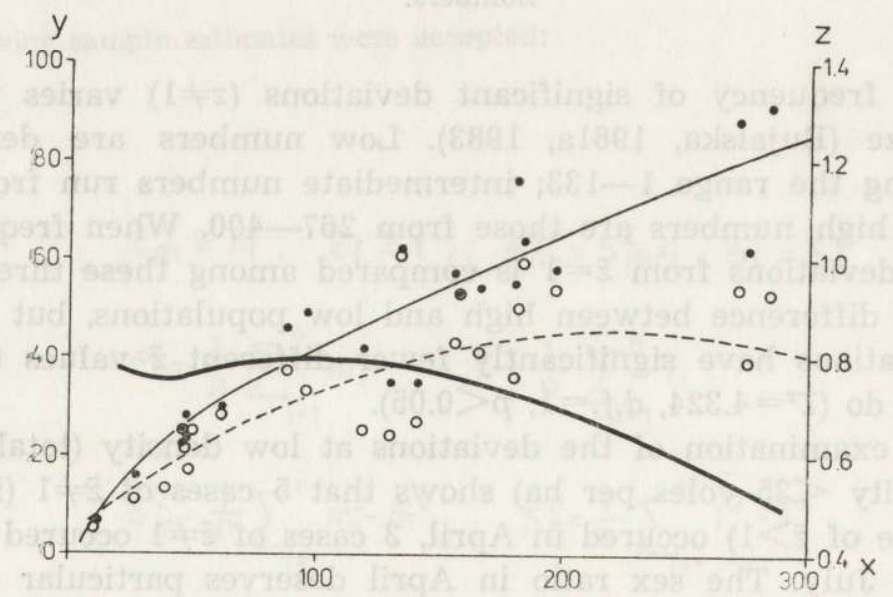

Fig. 2. Regression of number of mature males and that of females on size of the trappable population.

$y-$ number of mature individuals, $x-$ population numbers, $\hat{z}-$ sex ratio expected from the regressions (denoted by the thick continuous line).

Dots and thin continuous line denote females $\left(y=V-\overline{-120.48+14.58 x+0.0357 x^{2}}\right.$, $R=0.883, n=24, F=37.22, \quad p<0.001)$, open circles and dashed line denote males $\left(y=3.51+0.375 x-8.376^{-04} x^{2}, R=0.823, n=24, F=21.03, p<0.001\right)$.

Among immature voles, however, there was a tendency toward numerical preponderance of males over females (Bujalska, 1981a, 1983). In 8 cases of 21 available the $\bar{z}$ value was significantly higher than 1 , and it was never found to be significantly less than 1 . Thus a reversal of sex ratios seems to accompany sexual maturation.

As was shown earlier (Bujalska, 1970, 1973, 1985) the number of mature females is relatively stable and independent of population numbers from June to September due to a tendency toward territoriality. 
Data for both sexes from 1975-80, when simultaneous estimates of the numbers of mature males and females were available, are shown in Figure 2. In spite of similar regression formulas, which seem to describe well enough the numerical changes of mature voles of both sexes accompanying the increase of population numbers, the regression coefficients are different, and female curve is always at a higher level than that of the males. This is indicative of different vulnerability of mature males and females to elements of environmental capacity such as food or space. The variable environmental capacity induces changes in spatial structure of the mature segment of the population which are shown by changes in home range size or amount of home range overlap (Bujalska, 1975, Bujalska \& Janion, 1981). Thus, under given conditions a particular number of mature individuals matches the environmental capacity. As a consequence one may suppose that in populations characterized by limitation of numbers of mature individuals due to their spacing behaviour the sex ratio in mature animals varies inde-

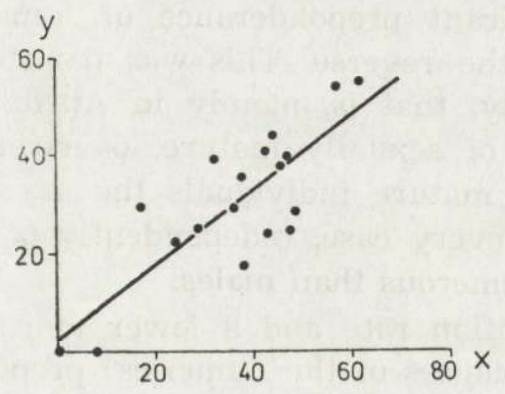

Fig. 3. Correlation between mortality rate of mature males and females.

$y$ - percent mortality of mature females from one census to the next, $x-$ percent mortality of mature males from one census to the next, $\hat{y}=2.51+0.756 x$, $n=18, r=+0.817, p<0.001$.

pendently of population density. On the other hand, if such limitation does not occur, or if it occurs only within a certain range of population density, the number of mature males and females ought to increase with density, and changes in sex ratio can be regarded as density-dependent (Bujalska, 1981b).

A question thus arises as to why the sex ratio is so frequently biased in favour of mature females. One obvious possibility is that mature males have a higher mortality rate than mature females. The mortality rate from each census to the next was calculated for mature males and females separately. Although there is a significant linear correlation between mortality rates of males and females (Fig. 3), the slope of the regression line is $<1$, which suggests a higher rates for males than 
for females. Males, in fact, had the higher rate in 15 of 18 available cases, and the average mortality of males $(39.8 \%, n=583)$ was higher than that of females $(32.7 \%, n=745), U=2.656, p<0.01$. Hence, mature males die out at a higher rate than mature females.

A second possibility is a lower maturation rate among males than among females. Although only 7 cases are available for comparison the mean maturation rate - as expressed in the percentages attaining maturity in a 6 week interval dividing consecutive censuses - is lower for males $(34.7 \%, n=311)$ than for females $(45.7 \%, n=232), U=2.632$, $p<0.01$. Thus, the female-biased sex ratio is associated with both a higher mortality rate and a lower maturation rate of males. Supposedly, the male maturation rate matches the environmental capacity for mature males, and - as in mature females - by their spatial requirements.

\section{CONCLUSIONS}

1. Though the sex ratio in all the trappable voles was in most cases equal to 1 , a significant preponderance of females over males was more frequent than the reverse. This was particularly pronounced at low population density, that is, mainly in April when the population consisted exclusively of sexually mature, overwintered voles.

2. Among sexually mature individuals the sex ratio frequently differed from 1 and in every case, independently of population numbers, females were more numerous than males.

3. A higher maturation rate and a lower mortaliy rate among mature females are the causes of the numerical preponderance of females.

4. Different spatial requirements of mature males and females are a means of adjusting the number of reproducing animals to actual environmental conditions. Hence, sex ratio among mature individuals may be variable and independent of population density. On the other hand, in population characterized by unlimited maturation and natality, the sex ratio among mature individuals may simply be a function of density.

Acknowledgements: I am greatly indebted to Dr. W. A. Fuller of the University of Alberta, Canada, for critical comments.

\section{REFERENCES}

1. Bergstedt B., 1965: Distribution, reproduction, growth and dynamics of the rodint species Clethrionomys glareolus (Schreber), Apodemus flavicollis (Melchior) and Apodemus silvaticus (Linné) in southern Sweden. Oikos, 16: 132-160 .

2. Bujalska G., 1970: Reproduction stabilizing elements in an island population of Clethrionomys glareolus (Schreber, 1780). Acta theriol., 15: 381-412.

3. Bujalska G., 1973: The role of spacing behavior among females in the regulation of reproduction in the bank vole. J. Reprod. Fert. Suppl., 19: 463-472. 
4. Bujalska G., 1975: The effect of supplementary food on some parameters in an island population of Clethrionomys glareolus (Schreber, 1780). Bull. Acad. pol. Sci. Ser. Sci. biol. Cl. II, 23: 23-28.

5. Bujalska G., 1981a: Formation of sex structure in populations of bank vole (Clethrionomys glareolus Schreber, 1780). Wiad. ekol., 27: 37-48. [In Polish with English summary.]

6. Bujalska G., 1981b: Reproduction strategies in populations of Microtus arvalis and Apodemus agrarius inhabiting farmland. Pol. ekol. Stud., 7: 229-243.

7. Bujalska G., 1983: Sex ratio [In: "Ecology of the bank vole", Ed. K. Petrusewicz]. Acta theriol., 28, Suppl. 1: 103-111.

8. Bujalska G., 1985: Fluctuations in an island bank vole population in the light of the study on its organization. Acta theriol., 30: 3-49.

9. Bujalska G. \& .Tanion S. M., 1981: Bank vole response to an increase of environmental capacity. Bull. Acad. pol. Sci. Ser. Sci. biol. Cl. II, 29: 129-133.

10. Dunin-Barkovskij I. V. \& Smirnov N. V., 1955: Teorija verojatnostej i matematičeskaja statistika $\mathrm{v}$ technikie (obšcaja cast). Izd. Techniko-Teoretičeskoi Literatury: 1-556. Moskva.

11. Hansson L., 1978: Sex ratio in small mammal populations as affected by the pattern of fluctuations. Acta theriol., 23: 203-212.

12. Jolly G. M., 1965: Explicit estimates from capture-recapture data with both death and dilution - stochastic model. Biometrika, 52: 225-247.

13. Kalela O., 1971: Seasonal trends in the sex ratio of the grey-sided vole Clethrionomys rufocanus (Sund.). Ann. Zool. Fennici, 8: 452-455.

14. Lidicker W. Z. Jr., 1973: Regulation of numbers in an island population of the California vole, a problem in community dynamics. Ecol. Monogr., 43: 271-302.

15. Myers J. H. \& Krebs C. J., 1971: Sex ratio in open and enclosed vole population: demographic implications. Amer. Natur., 105: 325-344.

16. Pelikán J., 1970: Sex ratio in three Apodemus species. Zool. Listy, 19: 23-34.

17. Pucek M., 1983: Habitat preference [In: "Ecology of the bank vole", Ed. K. Petrusewicz]. Acta theriol., 28: Suppl. 1: 31-40.

18. Redfield J. A., Taitt M. J. \& Krebs C. J., 1976; Experimental alteration of sex ratios in populations of Microtus townsendii, a field vole. Can. .J. Zool., 56: $17-27$.

Accepted, May 27, 1985.

Gabriela BUJALSKA

PROPORCJE PECI W WYSPOWEJ POPULACJI CLETHRIONOMYS GLAREOLUS (SCHREBER, 1780)

Streszczenie

Badania nad proporcjami płci (wyrażonymi stosunkiem liczbowym wszystkich samców do samic, $\bar{z}$ ) prowadzono - stosując metodę CMR - w latach 1966-70, 1972 i 1975-80. Dla ostatnich sześciu lat badań dysponowano ponadto obserwacjami proporcji płci wśród osobników dojrzałych płciowo. 
Wykazano, że proporcje płci wśród wszystkich osobników były w większoścj przypadków równe 1 . Różne od 1 proporcje płci istotnie częściej wskazywały na przewagę samic (Ryc. 1). Szczególnie często przewagę samic obserwowano w kwietniu (najniższe wartości liczebności populacji). W październiku proporcje płci rzadko odbiegały od 1 - przewaga samic na wiosnę musiała być rezultatem różnej śmiertelności zimowej (Tabela 1).

Wśród dojrzałych osobników obserwowano przewagę samic (Ryc. 2). Było to rezultatem: (1) Wyższej śmiertelności dojrzałych samców niż samic (Ryc. 3). Srednia śmiertelność dojrzalych samców wynosiła $39.8 \%$ a samic $-32.7 \%, \mathrm{p}<0.01$. (2) Niższego tempa dojrzewania samców niż samic (odpowiednio $34.7 \%$ i $45.7 \%$, $\mathrm{p}<0.01$ ).

Hamowanie tempa dojrzewania samców i samic (na drodze tendencji terytorialnych) sprawia, że proporcje płci wśród dojrzałych osobników są niezależne od gęstości populacji (Ryc. 3). 